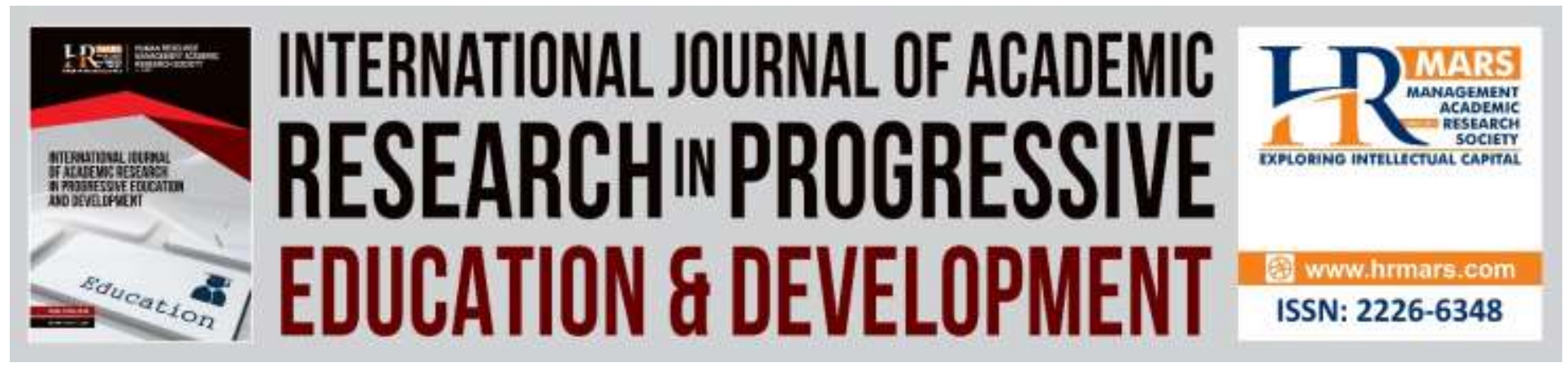

\title{
Teaching Hadith Subjects through E-Learning Methods: Prospects and Challenges
}

Mesbahul Hoque, Adnan Mohamed Yusoff, Abdul Karim Toure, Yuslina Mohamed

To Link this Article: http://dx.doi.org/10.6007/IJARPED/v8-i2/6164

DOI: 10.6007/IJARPED/v8-i2/6164

Received: 15 Jan 2019, Revised: 16 Feb 2019, Accepted: 12 March 2019

Published Online: 29 March 2019

In-Text Citation: (Hoque, Yusoff, Toure, \& Mohamed, 2019)

To Cite this Article: Hoque, M., Yusoff, A. M., Toure, A. K., \& Mohamed, Y. (2019). Teaching Hadith Subjects through E-Learning Methods: Prospects and Challenges. International Journal of Academic Research in Progressive Education and Development, 8(2), 507-514.

Copyright: (c) 2019 The Author(s)

Published by Human Resource Management Academic Research Society (www.hrmars.com)

This article is published under the Creative Commons Attribution (CC BY 4.0) license. Anyone may reproduce, distribute, translate and create derivative works of this article (for both commercial and non-commercial purposes), subject to full attribution to the original publication and authors. The full terms of this license may be seen

at: http://creativecommons.org/licences/by/4.0/legalcode

Vol. 8(2) 2019, Pg. 507 - 514

http://hrmars.com/index.php/pages/detail/IJARPED

JOURNAL HOMEPAGE

Full Terms \& Conditions of access and use can be found at http://hrmars.com/index.php/pages/detail/publication-ethics 


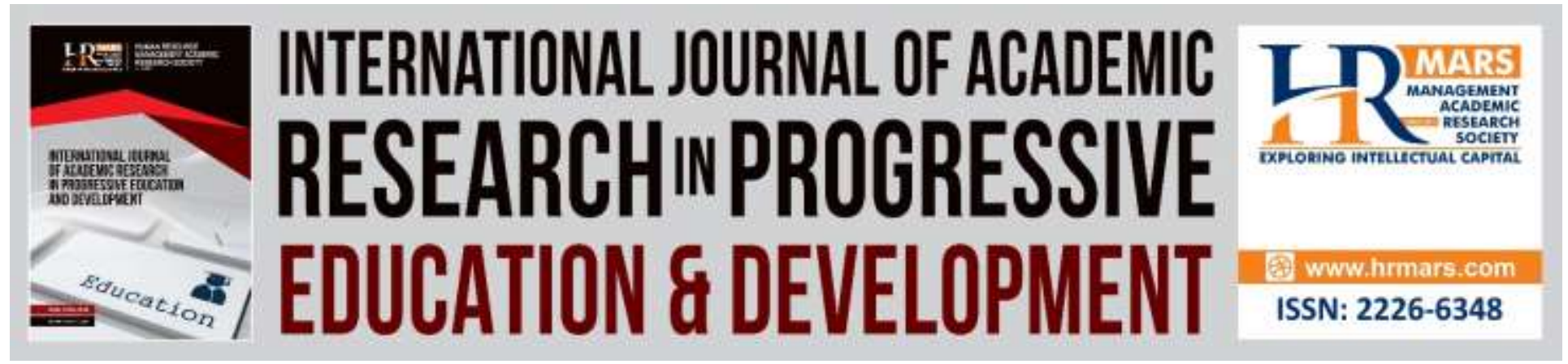

\title{
Teaching Hadith Subjects through E-Learning Methods: Prospects and Challenges
}

\section{Mesbahul Hoque ${ }^{1}$, Adnan Mohamed Yusoff ${ }^{2}$, Abdul Karim Toure $^{3}$, Yuslina mohamed ${ }^{4}$.}

${ }^{1}$ Senior Lecturer Faculty of Quranic and Sunnah studies, University Sains Islam Malaysia (USIM)

${ }^{2}$ Associate Professor Faculty of Quranic and Sunnah studies, University Sains Islam Malaysia

(USIM), ${ }^{3}$ Senior Lecturer Faculty of Quranic and Sunnah studies, University Sains Islam

Malaysia (USIM), ${ }^{4}$ Senior Lecturer Faculty of Major language studies, University Sains Islam Malaysia (USIM)

\begin{abstract}
The number of E-learning resources available to educators has dramatically increased even Within Islamic education. A lot of Repositories or digital Islamic libraries have been established to manage access to E-learning materials. This prompted many Islamic universities to adopt Elearning methods in their educational system nowadays. One of the most important and popular Islamic sources is Hadith. "Ulomul al-hadith" (sciences of hadith) "Takhri" (a method and authentic way of searching the source of Hadith), "Ilmu Al-Rijal" (study biography of narrators), "Derasa Al-Isnad" (identify the reliability of narrators) and "Hokum Al-Hadith" (determine the validity of Hadith) etc are subjects related to the hadith. The objective of this paper to highlights the Prospects and Challenges of teaching these subjects through E-Learning Methods and it's concluded that, it is indispensable to take advantage of the modern technological facilities in the study of Hadith.
\end{abstract}

Keywords: E-learning, Hadith, Methods, Teaching, Challenges.

\section{Introduction}

Several terms are used in describing the teaching of Islam including Islamic Education, Islamic Religious Education, Islamic Studies, and Islamic Sciences. Although sometimes used interchangeably, Islamic Education is broader than the other terms and it means a system or paradigm of education in the Islamic spirit which has no segregation between "religious" and "secular" knowledge. It aims at developing the entire human aspects physically, intellectually and spiritually as well as educating a person to be aware about his nature as a man and his roles as the servant of God and his vicegerent on this earth (Ali \& Bagley, 2013).

However, Islamic Studies, Islamic Sciences and Islamic Religious Education mean the teaching of the heritage of Islamic theology through the Qur'an and the Sunnah. Generally includes: Quran 
recitation (Qiraa), memorisation (Hifdh) and interpretation (Tafsiir); Prophet's Sayings and Practices (Hadith), Islamic Jurisprudence (Fiqh), Islamic basic beliefs (Aquiidah), Arabic Language, grammar, prose, rhetoric, literature, Islamic Rituals, Islamic History, Islamic Manners and Values (Shah, Ghazi, Din, Shahzad, \& Ullah, 2015).

\section{Philosophy and Objective of Islamic Education}

Education in Islam is "an education which trains the sensibility of an individual, in such a manner that their attitude towards life, their actions, decisions and approach to all kinds of knowledge are governed by the spiritual and deeply felt ethical values of Islam". The philosophy of education in Islam is repeatedly emphasized in the Quran. Other than this, there are also several hadiths and sayings of the companions that are related to education. Learning is an aspect of worship in Islam. Education in Islamic perspective is a purposeful process based on the principles of Islam, which aims at educating human being socially, ethically, emotionally and physically in order to achieve complete submission to Allah (Khan, 1981). It prepares human beings for holistic life with no separation of this temporary life which ends with death, and the eternal life that begins after death. It is a means of training the body, mind and soul through imparting the knowledge of all kinds i.e. fundamental as compulsory and specialised as optional (yasin \& Jani,2013). Education in Islam is not merely of acquiring intellectual knowledge, but it is a mean of moulding the nature and character of an individual so that they can collectively represent Islamic values, behave as khalīfatullāh fi al-ard (vicegerent of Allāh on the earth), (Husain \& Ashraf, 1979). In another word, education is "a process through which human beings are trained and prepared in a concerted way to do their Creator's bidding in this life (dunyā) to be rewarded in the life after death (äkhirah)". To ensure that people fulfill their roles as 'abd and khalifah, all of their intellectual, physical, spiritual, emotional, moral, social, and other potentials have to be developed. Therefore, the role of education and instruction is to initiate the germination and later flowering of each child's potential. To this effect, Islamic education is designed to produce God-conscious (taqwa) people who serve Him and who are aware of their individual vertical relations with Him (hablu min Allah) and their horizontal social relations with their fellow human beings (hablu mina al-nas). A good person, or the 'abd in the Islamic perspective, will also be concerned about social justice, as were the Prophet and his Companions, all of whom commanded Muslims to disseminate good and eliminate evil (amr bi al-ma 'ruf wa nahiy 'an al-munkar). Clearly, then, the good person is one who is active and dynamic, always concerned with justice, fully devoted to seeking God's favor, and always conscious of the need to worship Him alone (Hashim, 2007).

On the other side, the objective of education is to produce effective society members for the development of the nation having good ethical and moral values. These members are produced through education system. The same ideology is presented by all the religions in general, specifically by Islam. The objective of education will remain the same, either it would be in traditional educational system or e-learning educational system. The traditional educational system is somehow fulfilling this objective because of matured policies but e-learning educational system is still struggling to meet the target, as this new mode of education have lot of challenges and deficiencies. 
Vol. 8, No. 2, 2019, E-ISSN: 2226-6348 @ 2019 HRMARS

\section{Definitions of E-Learning}

Commercialization of internet in education has prompt a new method of teaching which is known as electronic learning (E-learning). E-learning is also called Web-based learning, online learning, distributed learning, computer-assisted instruction, or Internet-based learning. Elearning content is delivered via the Internet, intranet or extranet, audio or videotape, satellite TV, and CD-ROM. It can be self-paced or instructor- led and includes media in the form of text, image, animation, streaming video and audio. Ghavifekr and Rosdy defined E-learning as capability of experiencing learning process by using technology to design, deliver, select, administer, support and extend the learning process (Ghavifekr \& Rosdy, 2015). While Abbad, et al (2009) defined E-learning to mean any learning that is enabled electronically. They however narrowed this definition down to mean learning that is empowered using digital technologies. Welsh et al. (2003) also referred to the term as the use of computer network technology, principally through the internet, to provide information and instruction to individuals. It can be concluded from the above that, E-learning refers to the use of information and communication technologies to enable the access to online learning/teaching resources.

Historically, there have been two common e-learning modes: distance learning and computer assisted instruction. Distance learning uses information technologies to deliver instruction to learners who are at remote locations from a central site. Computer assisted instruction (also called computer-based learning and computer-based training) uses computers to aid in the delivery of stand-alone multimedia packages for learning and teaching. These two modes are subsumed under e-learning as the Internet becomes the integrating technology.

New E-learning technology continues to become increasingly accessed and implemented by people of all walks of life. Increasingly, the technologies are becoming more integrated as an invisible and ubiquitous part of a global education system.

\section{Advantages of E-Learning}

E-learning is very beneficial to both students and institutions. Using information technologies and Internet in the learning process higher learning Institutions aim to give students a greater autonomy regarding the point in time, the content and the method by which they learn by providing on demand learning, that eliminates the barriers of time and distance. Faculty, administrators, and learners find that e-learning has a lot of advantages (Chowdhury, 2017). These advantages can be categorized as targeting either learning delivery or learning enhancement.

Learning delivery is the most often cited advantage of e-learning and includes increased accessibility to information, ease in updating content, personalized instruction, ease of distribution, standardization of content, and accountability. Accessibility refers to the user's ability to find what is needed, when it is needed. Improved access to educational materials is crucial, as learning is often an unplanned experience. Updating electronic content is easier than updating printed material. According to Suresh, et al (2018) E-learning technologies allow educators to revise their content simply and quickly. Learners have control over the content, learning sequence, pace of learning, time, and, often, media, which allows them to tailor their experience to meet personal learning objectives. Internet technologies permit the widespread distribution of digital content to many users simultaneously anytime and anywhere. An 
additional strength of e-learning is that it standardizes course content and delivery; unlike, for instance, a lecture given to separate sections of the same course. Automated tracking and reporting of learners' activities lessen faculty administrative burden. Moreover, e-learning can be designed to include outcomes assessment to determine whether learning has occurred.

The advantages in learning enhancement are a less well recognized but potentially more revolutionary aspect of e-learning than are those related to learning delivery. E-learning technologies offer educators a new paradigm, based on adult learning theory, which states that adults learn by relating new learning to past experiences, by linking learning to specific needs, and by practically applying learning, resulting in more effective and efficient learning experiences. Learning enhancement permits greater learner interactivity and promotes learners' efficiency, motivation, cognitive effectiveness, and flexibility of learning style (Okpo, 2014). Learning is a deeply personal experience: we learn because we want to learn. By enabling learners to be more active participants, a well-designed e-learning experience can motivate them to become more engaged with the content. Interactive learning shifts the focus from a passive, teacher-centred model to one that is active and learner-centred, offering a stronger learning stimulus. Interactivity helps to maintain the learner's interest and provides a means for individual practice and reinforcement. Evidence suggests that e-learning is more efficient because learners gain knowledge, skills, and attitudes faster than through traditional instructor-led methods. This efficiency is likely to translate into improved motivation and performance. E-learners have demonstrated increased retention rates and better utilization of content, resulting in better achievement of knowledge, skills, and attitudes (Taylor \& Parsons, 2011). On the other hand, Multimedia e-learning offers learners the flexibility to select from a large menu of media options to accommodate their diverse learning styles.

\section{E- Learning Challenges in Higher Education}

Responding to the widely used of the E-learning services, several studies were conducted on ELearning methods in Higher Education focus its reliability and challenges. For example: Nurul Islam in his study find out five main E-Learning challenges faced by academics in Higher Education generally, learning style and cultural challenges, pedagogical e-learning challenges, technological challenges, technical training challenges and time management challenges (Islam, Beer, \& Slack, 2015). Ghinea, (2013) explored some different challenges and barriers which influenced acceptance of e-learning in Kuwaitian Higher Education institutions such as technological and language barriers, lack of management awareness and support in implementing e-learning in Kuwait HE system. On the other hand, Shihab A. Hameed in his study highlights ethical and moral challenges in e-learning based Education. (Rufai, 2016). According to Musbah \& Muhammad, (2013) Unethical behaviours can be categorized into four academic dishonesty which are cheating in tests, seeking outside help, plagiarism and electronic cheating.

\section{E-Learning Challenges in Teaching Hadith}

One of the most important Islamic subjects is Hadith. Hadith is the speech, deeds, actions, and characteristics of Prophet Mohammad (peace be upon him). It is considered the second source of legalisation in Islam after the Quran (Santeri \& Hoque, 2014). Students who are learning hadith 
in Higher Education they need to study some subjects related to Hadith such as: Al-Takhreej, Derasa Al-Isnad, IImu Al-Jarh and Al-Tadeel, and classify the Grade of Hadith, etc.

Many studies have been conducted to analyze the technology effectiveness in the study of the Hadith amongst university students. Hassan, et al (2015) in his study titled 'Modern Technology Application in Empowering Sunnah Education in the Globalization Era' (Aplikasi Teknologi Moden Dalam Memantapkan Pendidikan Sunnah Di Era Globalisasi) had discussed on several technologies which have been accepted and used in teaching and learning the study of Hadith. Technology has proven to give positive effects in facilitating effective and dynamic education, but simultaneously there are some challenges and weaknesses that need to be wisely handled; for example, dissemination of fake Hadith among society. (Khair, N. et al 2019). Another study which reviewed and identified characteristics of the E-Learning Courses in Hadith Science, from the Views of Students and Instructors in Virtual College in Iran. The results showed some factors in curriculum, such as the formulation of objectives, form of content presentation, determining learning activities and evaluation procedures were not in accordance with the guidelines. Also, in designing other elements of the curriculum such as learning resources and materials, teaching strategies has been noticed (Norollahee, et al, 2013). This study was at Iran. So, there is an apparent lack of study in dealing with characteristics of the E-Learning Courses in Hadith at Malaysian Universities. Hence, this research is expected to fill this existing gap of study.

\section{Conclusion}

Primary finding of study shows that, the adoption of E-learning in teaching Islamic subjects especially in subjects to the prophetic tradition hadith are very beneficial to both students and institutions, it can help the students to using information technologies and Internet in the learning process. Although there are a lot of advantages of e-Learning, it also has some challenges to replace traditional learning process. Following are some list of challenges which need to consider:

One of the biggest challenges in E- learning compared with traditional learning Ethical challenges, there are more chances for learners to deviate from educational objectives and behave unethically because of lack of physical interaction where learners have more freedom without proper monitoring of instructor.

Lack of physical interactions made e-learning students feel isolated and apprehensive. Lacking physical interaction may also affect the completion rate.

Physical classrooms, however, will enable learners to learn faster, as they can always refer to the instructors or peers for guidance.

Absent of body language in e-learning system might be effect in understanding and attention of learner.

E-learning may not be suitable for certain groups of learners, especially Ilmul Jarh Wa Al-Tadil students who need extensive hadith science laboratory experiments.

Moving into e-learning is difficult for instructors who are already familiar with the traditional teaching environment. This is because the e-learning teaching environment is new, and the elearning technologies are developing and changing rapidly.

Instructors need to have interpersonal skills to communicate effectively in an electronic classroom. As a result, instructors need e-learning training before transitioning. 
E-learners need additional courses, encouragement, support and motivation in order to get used to an e-learning environment and complete successfully their activities.

This is some general challenges for teaching Hadith subjects through e-learning methods. It is difficult for Muslim academic organizations to achieve objectives of education in current eLearning system. So, they should rethink their approaches for their identity.

\section{References}

Abbad, M. M., Morris, D., \& Nahlik, D. C. (2009). Looking under the Bonnet: Factors Affecting Student Adoption of E-Learning Systems in Jordan. The International Review of Research in Open and Distance Learning. 10 (2), 2.

Ali, F., Bagley, C. (2013). Islamic Education and Multiculturalism. Journal of Contemporary Issues in Education, 8(2), 19-31

Chowdhury, M. H., Rab, M., Said, W., Ghazali, N., Mohamed, Y., \& Toure, A. K. (2017). Application of Modern Technology in the Study of Hadith and Its Sciences: A Case Study. Advanced Science Letters, 23 (5), 4773-4776.

Ghavifekr, S. \& Rosdy, W. A. W.(2015). Teaching and learning with technology: Effectiveness ofICT integration in schools. International Journal of Research in Education and Science (IJRES), 1(2),175-191.

Ghinea, M. (2013). E-learning in Higher Educational Institutions in Kuwait: Experiences and Challenges. Published in International Journal of Advanced Computer Science and Applications 4(4).

Hashim, R. (2007). "Intellectualism in Higher Islamic Traditional Studies: Implications for the Curriculum". The American Journal of Islamic Social Sciences. 24.3. 97.

Hassan, S., Zakaria, S., Raus, M., \& Hanafi, L. H.(2015). Aplikasi Teknologi Moden Dalam Memantapkan Pendidikan Sunnah Di Era Globalisasi. Ma'alim Al-Qur'an Wa Al-Sunnah, 10(11), 1-12.

Islam, N., Beer, M., \& Slack, F.2015). E-Learning Challenges Faced by Academics in Higher Education. Journal of Education and Training Studies. Vol. 3 (5) 102-112.

Khair, N., Yama, P., Masrop, N., Nasir, M., Awang,A., \& Kechik, A. (2019). Mobile learning in the study of hadith: a study on students' understanding on the arrangement of sanad with specific symbol. International Journal of Modern Trends in Social Sciences. Vol:2(6),100114.

Khan, M. W. (1981). Education and Society in the Muslim World. Hodder \& Stoughton Ltd, Jeddah: King Abdul Aziz University, 23.

Musbah, K. \& Muhammad, A. (2013). Comprehensive E-Learning System Based on Islamic Principles. conference proceeding 5th International Conference on Information and Communication Technology for the Muslim World. 978.

Okpo, j. (2014). A New E-Learning Paradigm: Tools and Techniques. The Eurasia Proceedings of Educational \& Social Sciences (EPESS), Vol: 1, Pages 469-476.

Rufai, S. A. (2016). The Challenge of Curriculum Integration for Islamic Universities: Setting the Principles of Curriculum Integration. journal of educational studies, 4:1: 46 - 77.

Santeri, I., \& Hoque, M. (2014) "Mabahes fi Al-Hadith Al- Mawdu". Published by Dar Al-Sakir, Malaysia. 8-9. 


\section{INTERNATIONAL JOURNAL OF ACADEMIC RESEARCH IN PROGRESSIVE EDUCATION AND}

DEVELOPMENT

Vol. 8, No. 2, 2019, E-ISSN: 2226-6348 ๑ 2019 HRMARS

Shah, S. F., Ghazi, S. R., Din, M., Shahzad, S., \& Ullah, I. (2015). Quality and Features of Education in the Muslim World. Universal Journal of Educational Research, 3(4), 243-257.

Suresh, M., Priya, V., \& Gayathri, R. (2018). Effect of e-learning on academic performance of undergraduate students. Drug Invention Today, Vol 10 (9), 1997-1999.

Taylor, L., \& Parsons, J. (2011). Improving Student Engagement. Current Issues in Education,14(1).

Welsh, E. T., Wanberg, C. R., Brown, E. G., Simmering, M. J. (2003). E-learning: emerging uses, empirical results and future directions. International Journal of Training and Development. (7): 245-258.

Yasin, R. F, Jani, M. S. (2013) Islamic Education: The Philosophy, Aim, and Main Features. International Journal of Education and Research.Vol.1. 6.

\section{Corresponding Author}

Mesbahul Hoque

Email: mesbahul@usim.edu.my 